\title{
El professor
}

Montserrat Bacardí

Sempre que, per algun motiu, em ve al cap la idea d'un bon professor penso en Pere Rovira. Va ser el "meu" professor" de la "meva" matèria: la literatura. Sortosament, ho va ser els cinc cursos de la carrera, el de preparació per al doctorat i després va dirigir-me la tesina i la tesi. Fet i fet, el vaig tractar força uns deu anys, des del 1980, que vaig començar filologia espanyola a l'Estudi General de Lleida, fins al 1991, que vaig presentarhi la tesi.

El 1980 Pere Rovira tenia trenta-tres anys. Als nostres ulls postadolescents, semblava que en tingués molts més. El vèiem un "senyor", jove, però un "senyor": el bigoti, poblat i generós, li dissimulava el nas i la rialla; la veu, greu, li sortia de molt endins; els ulls li parlaven quan coincidien amb uns altres ulls; alt com és, caminava ben estirat; sovint duia americana, combinada amb bufandes i mocadors vistosos. La presència, vaja, ja imposava.

Dins les aules, també es mostrava seriós, professional. De seguida que entrava, anava per feina, sense gaires preàmbuls. S'asseia, treia els llibres de la cartera i començava a explicar. Si algú gosava interrompre'l, se'l veia content quan concernia el tema, però no s'enganxava als "pretexts" per a parlar de qualsevol altre assumpte vaporós. La literatura omplia totes les hores de classe.

Al llarg dels cursos, vam estudiar la literatura castellana de totes les èpoques, des de l'edat mitjana fins a la contemporaneïtat. Quantitativament i qualitativa, és una gran producció ("estrangera", ja aleshores, per a mi), que ell posava en relleu per mitjà d'una tria acurada d'autors i d'obres. El 1980 només feia dos anys que impartia classes a Lleida. Pel que explica a La finestra de Vermeer (2016), com que anava peix en literatura medieval, va haver de preparar-se-la de valent. La falta de memòria mai no m'ha impedit de recordar amb nitidesa les seves dissertacions sobre el Cantar de Mio Cid, el Libro de buen amor o La Celestina: gràcies a les lectures que en feia, generals i de detall, es van convertir 
en els nostres contemporanis - i encara avui ho són. En remarcava, sobretot, la vigència i el caràcter innovador, subversiu, sovint mitjançant la glossa d'alguns passatges igualment molt ben escollits. Ens feia adonar, així, del valor de cadascun dels mots i de la seva disposició. Com aquell qui res, ens introduïa en els mecanismes de la comprensió i de la interpretació crítica. Quantes vegades no havia pensat, enmig o després d'una classe: com es pot treure tant de suc de quatre paraules?

Explicada per ell, la literatura del Renaixement i del Barroc va esdevenir més amable i més entenedora: com oblidar que Garcilaso va ser el primer poeta pròpiament "modern" i Quevedo, tan polièdric, un gran poeta amorós, capaç d'escriure, al final d'un sonet memorable, "polvo serán, mas polvo enamorado"? Aquest i altres poemes seus, els havíem llegit del dret i del revés, buscant-hi un sentit més enllà dels mots i, encara més, una emoció. I la hi trobàvem, perquè ell la sentia i ens la transmetia.

Passades pel seu sedàs, les rimes de Bécquer, lluny de la carrincloneria, es van convertir en un gran artefacte literari — apassionant, naturalment. Igual que la poesia d'Antonio Machado o la de Luis Cernuda. O, més a prop, la de Jaime Gil de Biedma, a la qual ella havia dedicat la tesi i per la qual, pel que intuíem, sentia una gran afecció i una certa identificació. Les peripècies de la Maga de Rayuela, de Julio Cortázar, o de la família Buendia de Cien años de soledad, de Gabriel García Márquez, ens van proporcionar experiència literària i vital —que prou falta ens feia. Tant si ja ho havíem llegit com si no, tot ho descobríem de nou.

Alhora, ens parlava sovint de Josep Pla, de Joan Vinyoli o de Gabriel Ferrater, models d'ús de la llengua "viva", "oral”, "natural", la més difícil de plasmar literàriament, segons que ens repetia. De qualsevol text, en valorava, la "sinceritat”, l'“autenticitat", la versemblança: la veritat de la ficció. Dins de l'aula, el seu convenciment era tan ferm i, la commoció, tan tangible, que aviat tots, sense adonar-nos-en, vam situar la literatura al centre de l'univers. Una certa "sacralització" de l'objecte d'estudi li servia, no tan sols per a despertar-nos-en l'interès, sinó per a inocular-nos-en el virus per sempre més. En major o menor mesura, em penso que avui qualsevol dels seus deixebles podríem subscriure aquestes paraules del dietari La finestra de Vermeer: "Ja no sé sortir, ni vull, de la mania dels llibres".

Aquesta "mania" no es manifestava aïllada del món, separada del dia a dia: per captar la nostra atenció dispersa, establia múltiples connexions i paral-lelismes amb l'actualitat, que no sempre enteníem, però que endevinàvem importants. Ho feia, tot sovint, per mitjà de "sentències", frases breus i greus, un punt altisonants, que li sortien amb una facilitat envejable i que no permetien que se’ns n’anés el sant al cel ni, tampoc, tenir la temptació d'allargar el cafè abans de les classes. A l'hora, tothom hi compareixia, perquè es donava per sobreentès que valien la pena. Estranyament, no hi trobàvem pèls ni repèls. L'autoritat del professor passava per damunt les crítiques de les rotllanes desvagades. Ningú no en qüestionava les capacitats pedagògiques i, encara menys, els coneixements i la passió amb què els encomanava.

L'acompanyava, a més, una aureola de poeta. Per bé que aleshores només havia publicat un llibre, La segona persona (1979), introbable, aquell octubre del 1980 va guanyar el 
premi Vicent Andrés Estellés per Distàncies (1981), que alguns ens vam afanyar a llegir, per veure si hi descobríem la clau d'algun misteri indesxifrable. També l'envoltava una aureola de "conquistador": sabíem que s'havia separat i que vivia amb una alumna, la germana de la qual feia el nostre curs. Ella era alta, rossa i prima, maquíssima, i es deia Celina, un nom tan exòtic com suggestiu.

El darrer curs de carrera, a mesura que s'acostava el final, com que m'ho passava tan bé estudiant —és a dir, llegint i fent treballs—, vaig decidir que, d'una manera o altra, havia de continuar, que aquella deu de felicitat no podia estroncar-se. Recordo que un migdia de primavera de cinquè ens vam trobar, casualment, a la cantonada del carrer Major i el carrer de Cavallers, on fèiem les classes. Cap dels dos no va ser gaire loquaç ni explícit, però va quedar establert que faria els cursos de doctorat, que em dirigiria la tesina i que la faria sobre un poeta de Tàrrega, Alfons Costafreda. I així va ser. Després, tàcitament vam donar per descomptat que faria la tesi.

No sabia gaire on em posava, però volia llegir i escriure, i volia retrobar, ni que fos a estonetes, el paradís perdut que el món laboral m’obligava a deixar enrere. Vaig anar fent, a poc a poc, però sense gaires interrupcions. Sota el seu guiatge, vam fixar, d'entrada, unes lectures preliminars, unes fonts documentals i un esquema aproximat. Cada capítol que enllestia li enviava, ell me'l corregia de dalt a baix, paraula per paraula, i després el comentàvem. Com que ja vivia a Barcelona i el meu horari era complet, quedàvem els dissabtes a la tarda a casa seva, a Lleida. Asseguts al sofa, s'entretenia a explicar-me cadascuna de les esmenes, en unes sessions que duraven hores i hores, mentre la Celina, discreta i afable, ens oferia un cafè o, de tant en tant, ens preparava el sopar.

A pesar de tanta finesa i de tanta generositat, tremolava quan s'acostava alguna d'aquelles trobades, i no pas per les crítiques acadèmiques, que, quan hi eren, sempre anaven acomboiades de valoracions animoses. Simplement, hi assistia morta de vergonya, encongida, amb un sentiment de petitesa infinita i de destorb carregós. Això —i les trifulgues quotidianes - va fer que després no mantinguéssim un contacte més seguit.

Passats els anys — molts anys...-, m'agradaria pensar que no s'ha complert del tot el vaticini que Pere Rovira va fer al poema "El professor", de Cartes marcades (1988), sobre els seus alumnes:

Sap que es perdran, que es dissoldrà el desig de la paraula, el somni generós d'un altre amor, en l'aigua bruta de l'ofici sòrdid.

Oblidaran la poesia, que ara els regala temps, cors, alegria, noblesa i sofriment.

Moltes gràcies, mestre, per tants regals perdurables! 